\title{
KARAKTERISTIK GENOTIPE HIBRIDA HUNA BIRU (Cherax albertisii) DENGAN HUNA CAPITMERAH (Cherax quadricarinatus)
}

\author{
Irin Iriana Kusmini*, Estu Nugroho*), Alimuddin ${ }^{* *}$, dan Mulyasari*) \\ *) Balai Riset Perikanan Budidaya Air Tawar \\ Jl. Sempur Raya No.1, Bogor \\ E-mail: iriniriana@gmail.com \\ **) Departemen Budidaya Perairan_FPIK, Institut Pertanian Bogor \\ Jl. Lingkar Akademik, Kampus IPB Bogor 16680
}

(Naskah diterima: 8 April 2010; Disetujui publikasi: 27 April 2010)

\begin{abstract}
ABSTRAK
Pada pengelolaan induk di hatchery sering terjadi silang dalam (inbreeding) yang dapat menyebabkan terjadinya penurunan keragaman genetik. Salah satu program untuk meningkatkan keragaman genetik adalah dengan hibridisasi. Penelitian bertujuan untuk mengetahui keragaman genetik turunan persilangan antara huna biru Cherax albertisii dengan huna capitmerah Cherax quadricarinatus. Metode penelitian menggunakan analisis RAPD (Randomly Amplified Polymorphism DNA). Hasil penelitian menunjukkan nilai heterozigositas hibrida lebih tinggi $(0,187-0,290)$ dibanding nonhibrida (0,0997-0,2211). Hibridisasi antara jantan huna capitmerah dengan betina huna biru (RA) menghasilkan nilai heterozigositas yang lebih tinggi dibandingkan dengan persilangan antara betina huna capitmerah dengan jantan huna biru (AR).
\end{abstract}

KATA KUNCI: huna biru, huna capitmerah, genotipe, heterozigositas

ABSTRACT: Genotype characteristic of hybrid between blue crayfish (Cherax albertisii) and redclaw (Cherax quadricarinatus). By: Irin Iriana Kusmini, Estu Nugroho, Alimuddin, and Mulyasari

Management of fish broodstock in hatchery can reduced genetic variation. One program that can be conducted to increase the genetic variation is hibridization. The aim of this research was to find out genetic variation (heterozigosity) of the offspring of Cherax albertisii-Cherax quadricarinatus hybrid. The methods used in this research was RAPD analysis (Random Amplified Polymorphism DNA). The result showed that heterozigosity value of hybrid (0.187-0.290) was higher than that of non hybrid (0.0997-0.2211). Hybridization of redclaw male with blue crayfish female (RA) gave better result in heterozigosity value and genetic distance than that of redclaw female with blue crayfish male (AR).

KEYWORDS: Blue crayfish, redclaw, genotype, heterozigosity 


\section{PENDAHULUAN}

Pada pengelolaan induk di hatcheri sering terjadi silang dalam (inbreeding) yang dapat menyebabkan terjadinya penurunan keragaman genetik. Salah satu program untuk meningkatkan keragaman genetik adalah dengan hibridisasi. Huna capitmerah satu genus tetapi berbeda spesies dengan huna biru dan mempunyai kemiripan morfologi. Untuk meningkatkan kualitas benih sebar perlu penelitian persilangan (hibridisasi) antara huna capitmerah dengan huna biru.

Hibridisasi adalah memanfaatkan sifat heterosis karena sifat dominan dan heterozigot pada banyak lokus (Kapusckinski \& Jacobson, 1987) atau interaksi dari alela pada lokus (Tave, 1993). Hibridisasi berpengaruh dalam meningkatkan proporsi gen-gen yang heterozigot dan menurunkan proporsi gen yang homozigot (Falconer, 1996). Interspesifik hibridisasi adalah persilangan antar ikan yang berbeda spesies, yang dimaksudkan untuk memperoleh turunan yang tumbuh cepat, steril (triploid), tahan terhadap penyakit dan tahan terhadap perubahan lingkungan yang ekstrim (Hickling, 1968). Hibrid channel catfish betina $><$ catfish biru jantan menghasilkan turunan yang tumbuh lebih cepat dan lebih seragam (Brooks et al., 1982). Demikian juga dengan persilangan ikan-ikan jenis rainbow trout, dan brook trout tumbuh lebih cepat dari pada garis parental (induk) (Tave, 1993). Behrends \& Smitherman (1984) menyilangkan tilapia aurea yang tahan dingin dengan Red tilapia untuk menghasilkan populasi red tilapia yang tahan dingin. Menurut Lawrence (2005), di Australia persilangan antara betina Cherax roduntus $x$ jantan Cherax albitus menghasilkan turunan jantan semua, karena itu pertumbuhannya 4,8 kali lebih cepat setelah dipelihara selama 424 hari.

RAPD (Random Amplified Polymorphism DNA) adalah suatu aplikasi standar dari Polymerase Chain Reaction (PCR) yang digunakan untuk mendeteksi perbedaan polimorfik DNA yang ada antara spesies atau antar individu. Analisis RAPD terdiri atas tiga bagian, yaitu ekstraksi DNA, PCR, dan elektroforesis (Soewardi, 2007). Semakin banyak jumlah primer yang digunakan semakin besar peluang untuk mendeteksi polimorfik DNA, sehingga lebih mudah menganalisis keragaman genetiknya. Primer RAPD yang digunakan dalam penelitian ini adalah OPA08, OPA1 1, OPB02, OPB06, OPC03, dan OPC09, sebagaimana yang telah dilakukan Nguyen \& Austin (2004) di Australia, dengan menggunakan 60 primer, 10 primer di antaranya yang disebut di atas menunjukkan adanya 31 lokus yang berbeda antara Cherax destructor dengan turunan pertama ( $\mathrm{F}-1$ ) dan turunan kedua ( $\mathrm{F}-2)$.

Karakter genotipe diamati dengan RAPD, untuk mengetahui keragaman genetik (heterozigositas) dari turunan persilangan Cherax albertisii dengan Cherax quadricarinatus.
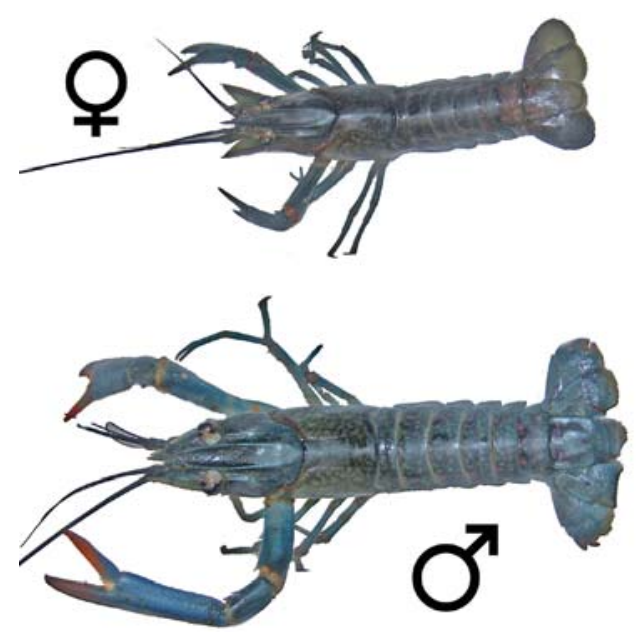

Gambar 1. Huna biru

Figure 1. Blue crayfish 


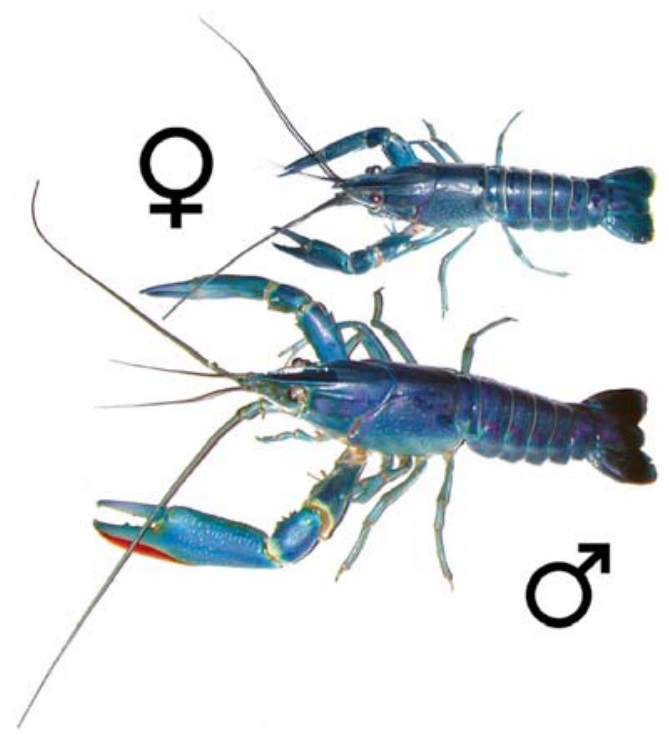

Gambar 2. Huna capitmerah

Figure 2. Redclaw

\section{BAHAN DAN METODE}

Benih-benih yang dihasilkan dari masingmasing induk betina dari perlakuan pemijahan di atas dipelihara secara terpisah sesuai dengan perlakuan dan ulangan induk. Kepadatan benih untuk masing-masing perlakuan dan ulangan adalah 80 ekor/bak tembok, ukuran bak tembok $2 \mathrm{~m} \times 2,5 \mathrm{~m} \times 0,8$ $\mathrm{m}$, dengan sistem air mengalir. Rancangan percobaan yang dilakukan dalam penelitian ini adalah rancangan acak lengkap dengan 4 perlakuan dan 3 ulangan.

\section{Prosedur Analisis RAPD}

\section{Ektraksi DNA}

DNA diekstraksi menggunakan metode Phenol-chloroform (Nugroho, 1997). Potongan antena atau kaki jalan dengan bobot 5-10 mg masing-masing induk huna yang disilangkan dan turunannya diambil, dan selanjutnya akan dimasukkan ke dalam tabung yang telah berisi $500 \mu \mathrm{L}$ larutan TNES urea. Kemudian sampel ditambahkan $15 \mu \mathrm{L} / \mathrm{mL}$ proteinase lalu divortex dan diikubasi pada suhu $55^{\circ} \mathrm{C}$ selama 1 jam.

Tabel 1. Skema perlakuan pemijahan huna biru dengan huna capitmerah Table 1. Spawning treatment scheme of blue crayfish and redclaw

\begin{tabular}{|c|c|c|}
\hline $\begin{array}{c}\text { Bet ina } \\
\text { Female }\end{array}$ & $\begin{array}{c}\text { Huna biru } \\
\text { Blue crayfish } \\
\text { (A) }\end{array}$ & $\begin{array}{l}\text { Huna capit merah } \\
\text { Redclaw } \\
\text { (R) }\end{array}$ \\
\hline Huna biru & AA & AR \\
\hline Blue crayfish & 1 jantan : 3 betina & 1 jantan : 3 betina \\
\hline (A) & 1 male: 3 female & 1 male : 3 female \\
\hline Huna capitmerah & RA & $\mathrm{RR}$ \\
\hline Redclaw & 1 jantan : 3 betina & 1 jantan : 3 betina \\
\hline (R) & 1 male : 3 female & 1 male : 3 female \\
\hline
\end{tabular}


Selanjutnya campuran tersebut divortex dan ditambahkan dengan larutan Phenol chloroform sebanyak 1.000 $\mu \mathrm{L}$. Lalu dilakukan sentrifugasi dengan kecepatan 10.000 rpm selama 10 menit. Supernatan yang terbentuk dipindahkan ke dalam tabung baru lalu ditambahkan $1.000 \mu \mathrm{L}$ larutan etanol 90\% dan natrium asetat $\left(\mathrm{NH}_{3} \mathrm{COONO}_{2}\right) 10 \mu \mathrm{L}$. Setelah itu campuran disentrifugasi dengan kecepatan $10.000 \mathrm{rpm}$ selama 10 menit hingga terbentuk endapan berwarna putih. Hasil dari campuran tersebut lalu dipisahkan antara DNA dengan larutan, DNA yang telah terpisah dikeringkan dalam suhu kamar. Selanjutnya DNA ditambahkan dengan 50-100 $\mu \mathrm{L}$ Rehydration Solution DNA.

\section{RAPD-PCR}

Primer yang digunakan dalam RAPD ini adalah OPA08, OPA 11 , OPB02, OPB06, OPC03, dan OPCO 9 dengan urutan basa tertera pada Tabel 2. Pengamplifikasian dilakukan menggunakan metode Polymerize Chain Reaction (PCR) dengan komposisi reaksi yang terdiri: $10 \mu \mathrm{g}$ DNA, $10 \mathrm{pmol}$ primer dan pure Taq DNA (Promega) dengan total volume keseluruhannya $25 \mu \mathrm{L}$. Program PCR yang digunakan dalam amplifikasi adalah predenaturasi pada suhu $95^{\circ} \mathrm{C}$ selama 4 menit, 35 siklus penggandaan yang terdiri atas $95^{\circ} \mathrm{C}$ selama 1 menit, $36^{\circ} \mathrm{C}$ selama 1 menit, $72^{\circ} \mathrm{C}$ selama 2,5 menit. Selanjutnya ekstensi akhir pada suhu $72^{\circ} \mathrm{C}$ selama 10 menit. Hasil PCR kemudian dipisahkan secara elektroforesis dengan menggunakan gel agarose $2 \%$ dalam Tris-Boric-EDTA (TBE) buffer dan diamati dengan illuminator (UV) serta dicetak gambarnya dengan polaroid.

\section{Analisis Heterozigositas}

Heterosigositas merupakan perpaduan dari alel-alel yang berbeda pada lokus yang sama dihitung berdasarkan persamaan HardyWeinberg, (Nei, 1978 dalam Miller, 1997). Program Tools for Population Genetic Analysis (TFPGA) digunakan untuk mencari kekerabatan antar perlakuan yang dihitung menurut Wright (1978) modifikasi dari Rogers (1972) dalam Miller (1997).

\section{HASIL DAN BAHASAN}

Dari 6 primer yang dicoba hanyai 1 primer menunjukkan hasil PCR yang baik. Primer OPA8 urutan basa 5'GTG ACG TAG G 3'mempunyai fragmen yang dapat digunakan sebagai pembeda diantara populasi huna yang diuji. Berdasarkan hasil analisis RAPD (Gambar 3), terlihat bahwa huna berada di antara berat molekul 275 bp sampai 1.400 bp. Berat molekul hibrida huna RA dan hibrida huna AR mendapat kontribusi berat molekul baik dari huna AA maupun huna RR.

Dari tipe DNA juga terlihat bahwa huna capitmerah (RR) yang telah lebih lama dibudidayakan mempunyai tipe DNA monomorfik jika dibandingkan dengan huna biru (AA) yang baru mulai dibudidayakan, di mana DNA huna biru mempunyai tipe DNA lebih polimorfik. Menurut Ricardo \& Taniguchi (1999), rata-rata polimorfisme yang berasal dari lingkungan budidaya lebih rendah dibandingkan dengan populasi yang terdapat di alam.

Keragaman genetik ditentukan oleh nilai rata-rata heterozigositas dan persentase polimorfisme. Hasil hibrid (AR \& RA)

Tabel 2. Primer RAPD yang digunakan untuk analisis DNA

Table 2. RAPD primers that used to analyze DNA

\begin{tabular}{|c|c|}
\hline $\begin{array}{l}\text { Nama } \\
\text { Name }\end{array}$ & $\begin{array}{l}\text { Urut an Basa 5'- 3', } \\
\text { Base sequence } 5^{\prime}-3^{\prime}\end{array}$ \\
\hline OPA08 & GTGACGTAGG \\
\hline OPA1 1 & CAATCGCCGT \\
\hline ОРВ02 & TGATCССТGG \\
\hline OРB06 & тGСТСТGССС \\
\hline OPC03 & GGGGGTCTTT \\
\hline OPC09 & СТCACСGTCC \\
\hline
\end{tabular}




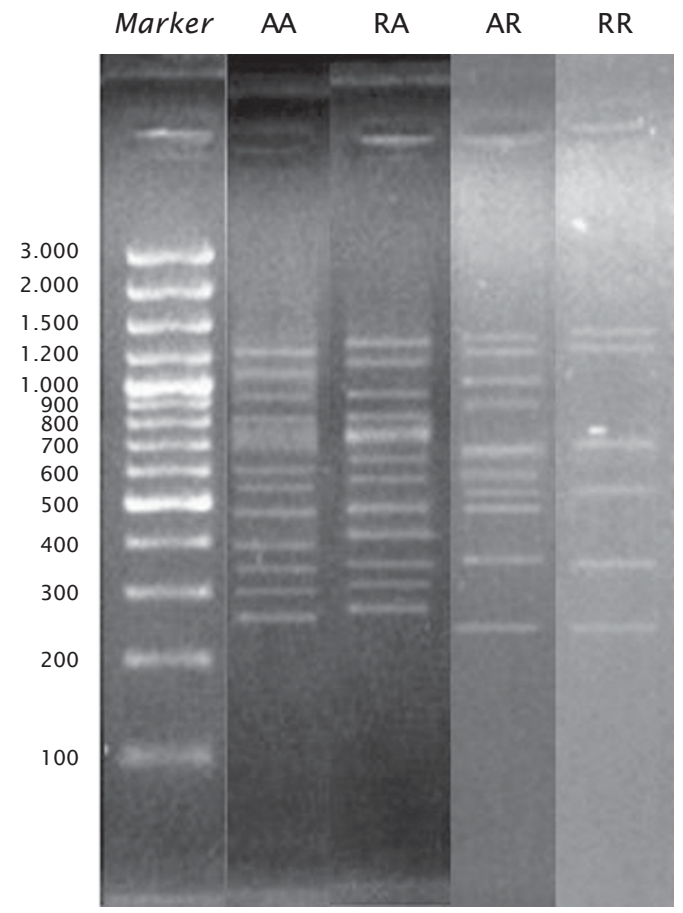

Gambar 3. RAPD hibrid huna capitmerah dengan huna biru menggunakan primer OPA8

Figure 3. RAPD profile of blue crafish-redclaw hybrid using primer OPA-8

menunjukkan nilai heterozigositas dan persentase polimorfisme lebih tinggi dibandingkan dengan huna nonhibrid (AA \& RR), nilai heterozigositas dan polimorfisme hibrid yang terpaut dengan asal induk betinanya memiliki nilai yang tinggi. Menurut Ryman \& Utter (1987), anak-anak hibrid mengekspresikan suatu kombinasi karakteristik yang terletak di antara kedua spesies induknya. Secara berurutan yang mempunyai nilai heterozigositas dan polimorfisme yang paling tinggi adalah perlakuan RA, kemudian AA, AR, dan RR (Tabel 3).

Tabel 3. Nilai heterozigositas dan persentase polimorfisme hibrida huna capitmerah-huna biru dengan RAPD menggunakan primer OPA-08

Table 3. Heterozigosity value and polimorphism percentage of blue crayfish-redclaw hybrid analyzed by RAPD using primer OPA-08

\begin{tabular}{lcccc}
\hline & AA & RR & AR & RA \\
\hline $\begin{array}{l}\text { Heterozigositas } \\
\begin{array}{l}\text { Heterozigosity } \\
\text { Polimorfisme } \\
\text { Polymorphism (\%) }\end{array}\end{array}$ & 0.2211 & 0.0997 & 0.1871 & 0.2907 \\
\hline
\end{tabular}


Tabel 4. Jarak genetik F-1 hibrida hasil hibridisasi antara huna biru (AA) dengan huna capitmerah (RR)

Table 4. Genetic distance of F-1 hybrid from blue crayfish (AA) with redclaw $(R R)$ hybridization

\begin{tabular}{ccccc}
\hline & AA & RR & AR & RA \\
\hline AA & xxxxxxxx & & & \\
RR & 0.4816 & xxxxxxxx & & \\
AR & 0.2966 & 0.0983 & xxxxxxxx & \\
RA & 0.1012 & 0.1705 & 0.0691 & xxxxxxxx \\
\hline
\end{tabular}

Heterozigositas RA lebih tinggi daripada $A R$, disebabkan adanya kontribusi gen dari induk betina AA yang mempunyai nilai heterozigositas lebih tinggi jika dibandingkan dengan RR. Hal ini menunjukkan bahwa keragaman genetik dari huna AA lebih tinggi dilihat dari nilai rata-rata heterozigositas, persentase polimorfisme, dan jarak genetik.

Berdasarkan perhitungan jarak genetik dari empat perlakuan diperoleh nilai jarak genetik terjauh antara AA dengan RR, diikuti dengan $A A$ dengan $A R$ dan RR dengan RA, AA dengan RA, sedangkan jarak yang terdekat adalah antara AR dengan RA dan antara RR dengan AR. Keragaman genetik juga dipengaruhi oleh perpindahan materi genetik antar dua populasi yang berbeda tempat (Soelistyawati, 1996). Jarak genetik terjauh adalah antara huna AA dengan huna RR hal ini disebabkan kedua huna tersebut berbeda spesies. Hibrida yang mendapatkan kontribusi gen dari induk betina cenderung memiliki jarak genetik yang lebih dekat dengan induk betina tersebut. Sedangkan jarak genetik antara AR dengan RA relatif dekat karena keduanya memiliki gen yang berasal dari pasangan induk jantan dan betinanya. Hasil ini memperlihatkan bahwa induk jantan dan betina berperan dalam mewariskan sifat pada keturunannya, di samping itu, kontribusi induk betina relatif lebih kuat (maternal effect) dibandingkan dengan induk jantannya. Menurut Saavedra \& Amat (2005), maternal effect dapat disebabkan oleh lingkungan dan genetik, selain itu, ekspresi dari beberapa gen dapat dipengaruhi oleh lingkungan. Hasil penelitian Nguyen \& Austin (2004) memperlihatkan bahwa 10 dari 60 primer RAPD di antaranya OPA08, OPA 11 , OPB02, OPB06, OPC03, dan OPC09, menunjukkan 31 lokus yang berbeda antara
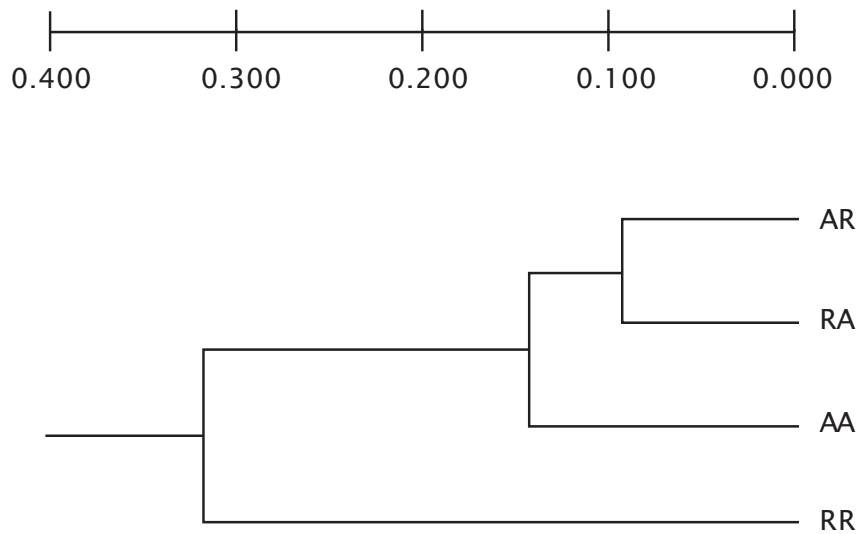

Gambar 4. Dendrogram F-1 hibrida hasil hibridisasi antara huna biru (AA) dengan huna capitmerah (RR)

Figure 4. Dendogram of F-1 hybrid from blue crayfish (AA) with redclaw $(R R)$ hybridization 
induk Cherax destruktor dengan turunan pertama ( $\mathrm{F}-1)$ dan turunan kedua ( $\mathrm{F}-2)$.

Dendrogram yang dibentuk berdasarkan jarak genetik digambarkan dalam tiga kluster utama. Hibrida AR dengan RA berada dalam satu kluster yang sama karena keduanya memiliki jarak genetik yang paling dekat $(0,0691)$ dibandingkan RA dengan RR atau RR dengan AA yang memiliki hubungan kekerabatan yang lebih jauh (Gambar 4).

\section{KESIMPULAN}

1. Nilai heterozigositas hibrida lebih tinggi $(0,187-0,290)$ dibanding nonhibrida $(0,0997-0,2211)$.

2. Hibridisasi antara jantan huna capitmerah dengan betina huna biru (RA) menghasilkan nilai heterozigositas yang lebih tinggi dibandingkan dengan AR.

3. Jarak genetik terdekat adalah antara hibrida RA dan hibrida AR, sedangkan jarak genetik terjauh adalah antara hibrida AR dengan RR.

\section{DAFTAR ACUAN}

Behrends, L.L. \& Smitherman, R.O. 1984. Development of a cold-tolerant population of red tilapia through introgressive hybridization. J. World Maricul. Soc., 15: 172-178.

Brooks, M.J., Smitherman, R.O., Chappell, J.A., \& Dunham, R.A. 1982. Sex-weight relation in blue channel, and white catfishes: Implication for brood stock selection. Prog. Fish Cult., 44: 105-107.

Falconer D.S. 1996. Introduction to quantitative genetics. Longman Malaysia, p. 281288.

Hickling, C. 1968. Fish hybridization. Proc. of world symp. on warm water pond fish culture. FAO Fish Rep. ,44: 1-10.

Kapusckinski, A.R. \& Jacobson, L.D. 1987. Genetic guidelines for fisheries management. Univ. of Minnesota, USA, 66 pp.
Lawrence, C.S. 2005. Yabby hibrid growth experiment. Fisheries Research Contract Report No. 11, FRDC. Project no. 97/3/9.02. Aquaculture Development Fund of Western Australia. Project, p. 1-7.

Miller, M.P. 1997. Tools For Population Genetic Analysis (TFPGA) version 1.3. Department of Biological Science. Northern Arizona University, Arizona, USA, 30 pp.

Nugroho, E. 1997. Practical manual on detection of DNA polymorphism in fish population study. Bulletin of Marine Science and Fisheries, 17: 109-129.

Nguyen, T.T.T. \& Austin, C.M.. 2004. Inheritance of molecular markers and sex in the Australian freshwater crayfish. Cherax destructor Clark. Aquaculture Research, 35 : 1,328-1,338.

Ricardo, P.E. \& Tanaguchi, N. 1999. Use of microsatellite DNA as genetic tags for the assessment of a stock enhancement program of red sea bream. J. Fish Sci., 65: 374-379.

Ryman, N. \& Utter, F. 1987. Population genetics and fishery management. Washington Sea Grant Program, London, p. 161-191.

Saavedra, C. \& Amat, F. 2005. Maternal effect on encysment in crosses between two geographic strains of Artemia franciscana. J. of Heredity, 96(6): 713-717.

Soelistyowati, D.T. 1996. Genetika populasi. Jurusan Budidaya Perikanan, Fakultas Perikanan. Institut Pertanian Bogor, 55 pp.

Soewardi, K. 2007. Pengelolaan keragaman genetik sumberdaya perikanan dan kelautan. Departemen Manajemen Sumberdaya Perairan. Fakultas Perikanan dan Ilmu Kelautan. Institut Pertanian Bogor, hlm. 112-119.

Tave, D. 1993. Genetics for fish managers. The AVI Publ. Comp. Inc. NY. USA, 415 pp. 